\title{
Penentuan Batas Pengelolaan Wilayah Laut Antara Provinsi Jawa Timur dan Provinsi Bali Berdasarkan Undang-Undang Republik Indonesia Nomor 23 Tahun 2014
}

\author{
Rainhard S Simatupang ${ }^{1)}$, Khomsin ${ }^{2)}$ \\ Jurusan Teknik Geomatika, Fakultas Teknik Sipil dan Perencanaan, Institut Teknologi Sepuluh Nopember (ITS), \\ Jl. Arief Rahman Hakim, Surabaya 60111 Indonesia $^{1,2)}$ \\ e-mail:khomsin@geodesy.its.ac.id ${ }^{2}$
}

\begin{abstract}
Abstrak --- Undang-Undang Republik Indonesia Nomor 23 Tahun 2014 Tentang Pemerintahan Daerah merupakan pembaharuan dari undang-undang sebelumnya yaitu UndangUndang Nomor 32 Tahun 2004 dikarenakan beberapa hal yang sudah tidak sesuai lagi dengan perkembangan keadaan pada saat ini [1]. Beberapa perubahan peraturan dalam hal penentuan batas wilayah pengelolaan laut daerah yang terkandung dalam UndangUndang Nomor 23 Tahun 2014 dari undang-undang sebelumnya yaitu mengenai penentuan garis pantai, batas wilayah bagi hasil kabupaten/kota, serta kewenangan setiap daerah baik provinsi maupun kabupaten/kota. Dalam Undang-Undang Nomor 23 Tahun 2014 ditetapkan bahwa batas maksimal wilayah laut provinsi sejauh 12 mil laut, sedangkan batas bagi hasil kelautan kabupaten/kota maksimal sejauh 4 mil laut. Apabila wilayah laut antar provinsi tidak mencapai batas maksimal masing-masing, maka batas akan dibagi sama jarak dengan prinsip garis tengah (median line). Penelitian ini merupakan bentuk pengaplikasian Undang-Undang Nomor 23 Tahun 2014 dalam memperbaharui penentuan batas pengelolaan wilayah laut daerah. Dalam penelitian ini akan dibahas bagaimana menentukan batas pengelolaan wilayah laut daerah serta dilakukan analisa dari hasil penentuan batas pengelolaan wilayah laut. Lokasi Penelitian ini adalah Provinsi Jawa Timur dan Provinsi Bali tepatnya perbatasan pada Kabupaten Banyuwangi (Jawa Timur) dan Kabupaten Buleleng (Bali) sampai Kabupaten Jembrana (Bali). Penentuan batas pengelolaan wilayah laut dilakukan dengan metode kartometrik menggunakan data Citra Satelit SPOT 72015 dan data Peta Lingkungan Pantai Indonesia (LPI) 2002. Dari penelitian ini dihasilkan median line sepanjang $40,3 \mathrm{~km}$ yang dibentuk oleh 41 titik, serta diperoleh luas wilayah pengelolaan laut Provinsi Jawa Timur sebesar 233,37 km$^{2}$ dan Provinsi Bali sebesar $233,77 \mathbf{k m}^{2}$ dengan selisih sebesar $0,4 \mathbf{~ k m}^{2}$ serta batas wilayah bagi hasil kelautan untuk kabupaten/kota. Dihasilkan juga peta batas pengelolaan wilayah laut daerah sesuai lokasi penelitian ini yang sudah berdasarkan UU No. 23 Tahun 2014.
\end{abstract}

Kata Kunci-Batas Pengelolaan Laut, Undang-Undang No. 23 Tahun 2014, Metode Kartometrik, Median Line.

\section{PENDAHULUAN}

I NDONESIA merupakan negara kepulauan yang memiliki luas lautan lebih besar dari luas daratannya. Berdasarkan data yang diperoleh dari Badan Informasi Geospasial (BIG), Indonesia adalah negara kepulauan terbesar di dunia dengan jumlah pulau 13.466, luas daratan 1.922 .570 $\mathrm{km}^{2}$ dan luas perairan $3.257 .483 \mathrm{~km}^{2}$ [2]. Dengan kondisi Indonesia yang demikian, tentu dibutuhkan perhatian khusus untuk mengatur permasalahan penentuan batas wilayah antar daerah terlebih batas wilayah laut sehingga dapat mengantisipasi terjadinya sengketa akibat tumpang tindih yang dapat menghambat proses pembangunan.

Batas administrasi suatu wilayah merupakan satu komponen pembagi kewenangan dan urusan untuk mewujudkan tertib administrasi daerah otonomi [1]. Hal tersebut telah dijelaskan dalam Undang-Undang Dasar Tahun 1945 Pasal 18 ayat (1) bahwa Negara Kesatuan Republik Indonesia (NKRI) dibagi atas daerah-daerah provinsi dan daerah provinsi tersebut dibagi atas kabupaten dan kota, dimana tiap-tiap provinsi, kabupaten dan kota mempunyai pemerintahan daerah yang diatur dengan undang-undang. Kurangnya perhatian pemerintah mengenai batas administrasi daerah terlebih batas wilayah laut dapat dilihat dari masih banyaknya wilayah laut antar daerah yang belum ditentukan secara tegas dan jelas dan dapat dilihat pada peta dasar yang ada pada saat ini. Kualitas akurasi sebuah peta dasar menjadi faktor yang sangat penting dalam penggunaannya. Sehingga, penentuan batas wilayah laut dapat diukur dengan akurat sesuai kondisi nyata dilapangan menggunakan peta dasar, baik itu peta digital maupun peta analog. Metode penarikan garis batas wilayah melalui peta dasar yang sudah terikat dengan koordinat referensi bumi dikenal dengan metode kartometrik.

Munculnya Undang-Undang Republik Indonesia No 23 Tahun 2014 Tentang Pemerintahan Daerah diharapkan dapat mempercepat terwujudnya kesejahteraan masyarakat melalui peningkatkan pelayanan, pemberdayaan, serta peran masyarakat dalam pemanfaatan sumber daya alam termasuk sektor kelautan dan perikanan [1]. Pada Undang-Undang No 23 Tahun 2014 dijelaskan bagaimana ketentuan dalam menetapkan batas wilayah laut suatu daerah serta ketentuan penetapan garis pantai yang digunakan untuk penarikan garis batas wilayah laut. Pada undang-undang sebelumnya, yaitu Undang-Undang Nomor 32 Tahun 2004 tidak dijelaskan secara spesifik mengenai penentuan garis pantai yang digunakan untuk penarikan batas pengelolaan wilayah laut daerah. Sedangkan pada Undang-Undang Nomor 23 Tahun 2014, garis pantai yang 
digunakan adalah garis pantai dari pasang tertinggi air laut yaitu high water level (HWL).

Provinsi Jawa Timur dan Provinsi Bali merupakan daerah yang wilayah lautnya saling berbatasan secara langsung. Wilayah laut perbatasan antara Provinsi Jawa Timur dan Provinsi Bali adalah kawasan yang berpotensi untuk penghasilan baik dari sumber daya alam kelautan dan perikanan maupun dari sektor pariwisata. Dengan kondisi demikian menjadikan kawasan ini butuh penegasan secara jelas mengenai batas pengelolaan wilayah lautnya.

Dalam penentuan batas pengelolaan wilayah laut daerah tentu dibutuhkan sebuah peta yang dapat dijadikan sebagai acuan untuk penarikan garis pantai serta penarikan batas pengelolaan wilayah laut daerah. Sementara Peta Lingkungan Pantai Indonesia (LPI) yang paling update adalah Peta LPI tahun 2002 (BIG). Dengan demikian garis pantai yang digunakan dalam peta tersebut belum sesuai dengan UndangUndang Nomor 23 Tahun 2014, sehingga butuh pembaharuan.

Oleh karena itu, dalam penelitian ini akan dibahas mengenai penentuan batas pengelolaan wilayah laut daerah antara Provinsi Jawa Timur dan Provinsi Bali berdasarkan UndangUndang Republik Indonesia Nomor 23 Tahun 2014 dengan menggunakan Citra Satelit Resolusi Tinggi (CSRT) tahun 2015 yang sudah terkoreksi sebagai acuan untuk penarikan garis pantai dan garis batas pengelolaan wilayah laut sesuai metode kartometrik.

\section{METODOLOGI PENELITIAN}

\section{A. Data dan Lokasi Penelitian}

Data yang digunakan dalam pelaksanaan penelitian ini adalah sebagai berikut:

1) Data Citra Satelit Resolusi Tinggi SPOT 7 tahun 2015 dengan ketelitian 1.5 meter yang diperoleh dari Lembaga Penerbangan dan Antariksa Nasional (LAPAN) yang menampilkan perbatasan wilayah laut antara Provinsi Jawa Timur dan Provinsi Bali.

2) Peta Lingkungan Pantai Indonesia (LPI) tahun 2002 yang diperoleh dari Badan Informasi Geospasial (BIG) sesuai derah penelitian yaitu perbatasan Provinsi Jawa Timur dan Bali dalam format shapefile (*.shp).

3) Undang-Undang Republik Indonesia Nomor 23 Tahun 2014.

4) Peraturan Menteri Dalam Negeri Nomor 76 Tahun 2012.

5) Data dan informasi lainnya yang mendukung terkait informasi penentuan batas wilayah pengelolaan laut antara Provinsi Jawa Timur dan Provinsi Bali.

Lokasi penelitian ini adalah kawasan perbatasan antara Provinsi Jawa Timur dan Provinsi Bali. Dimana, posisi geografis provinsi Jawa Timur terletak diantara $111^{\circ} 0^{\prime}-114^{\circ}$ $4^{\prime}$ Bujur Timur dan $7^{\circ} 12^{\prime}-8^{\circ} 48^{\prime}$ Lintang Selatan tepatnya pada Kabupaten Banyuwangi, sementara posisi geografis Provinsi Bali terletak diantara $114^{\circ} 25^{\prime}-115^{\circ} 42^{\prime}$ Bujur Timur dan $8^{\circ} 3^{\prime}-8^{\circ} 50^{\prime}$ Lintang Selatan, tepatnya pada bagian barat Kabupaten Buleleng sampai Kabupaten Jembrana.

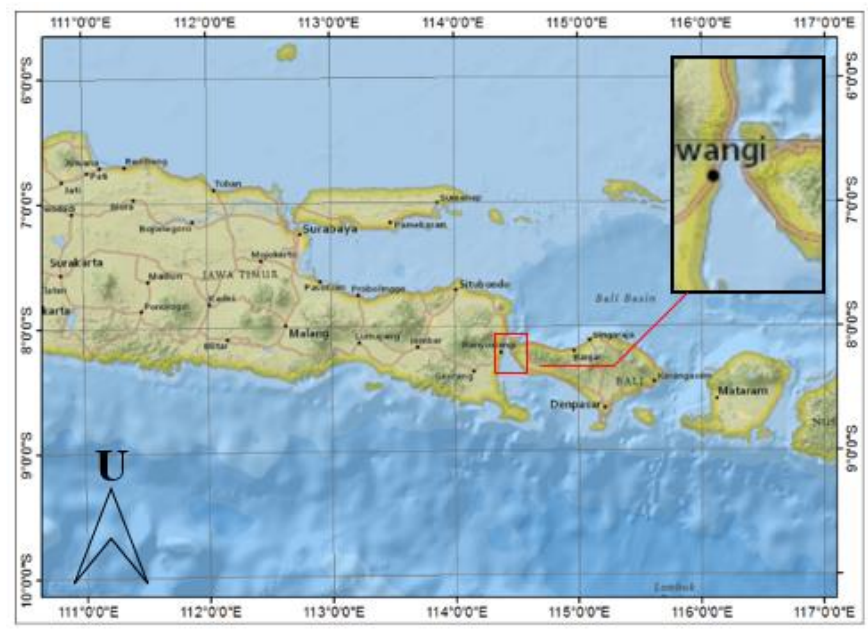

Gambar. 1. Lokasi Penelitian [8]

\section{B. Metode Penelitian}

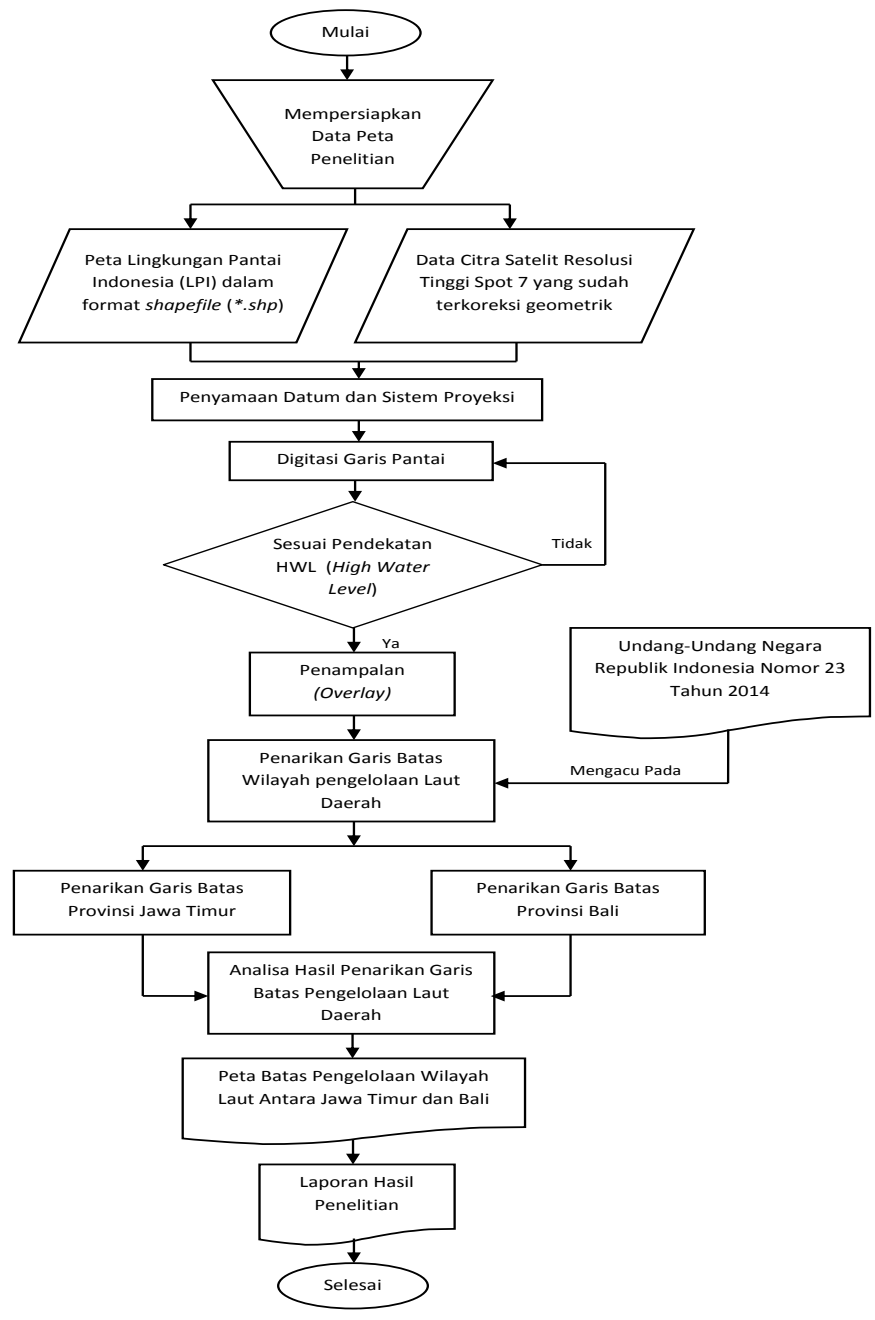

Gambar. 2. Diagram Alir Tahap Pengolahan Data

\section{HASIL DAN ANALISA}

\section{A. Hasil Digitasi Garis Pantai}

Setelah data citra satelit yang akan dijadikan dasar acuan sudah memiliki sistem koordinat yang sesuai dengan ketentuan, 
maka selanjutnya dilakukan digitasi terhadap garis pantai yang akan digunakan sebagai acuan penarikan batas pengelolaan wilayah laut daerah. Berdasarkan Undang-Undang Republik Indonesia Nomor 23 Tahun 2014 [1], garis pantai yang digunakan untuk penarikan batas pengelolaan wilayah laut daerah adalah batas pertemuan antara bagian laut dan daratan pada saat terjadi air laut pasang tertinggi.

Dalam menentukan garis pantai pada saat pasang tertinggi air laut (High Water Level) perlu dilakukan survei batimetri serta pengamatan pasang surut air laut agar dapat menghasilkan data yang lebih akurat. Namun metode tersebut akan membutuhkan waktu yang lama serta biaya yang yang lebih besar. Oleh sebab itu, untuk menghemat waktu dan biaya pengeluaran dalam pelaksanaan penelitian ini, penentuan garis pantai pada saat kondisi pasang tertinggi air laut seperti yang telah ditetapkan dalam Undang-Undang Nomor 23 Tahun 2014 dilakukan dengan sebuah pendekatan. Pendekatan penentuan garis pantai pada saat terjadi pasang air laut tertinggi tersebut dilakukan berdasarkan karakteristik pantai dan unsur-unsur pembentuknya [3]. Berikut adalah metode pendekatan dalam penentuan garis pantai pada pasang tertinggi air laut berdasarkan karakteristik pantai dan unsur-unsur penyusunnya:

1) Daerah pantai pasir, garis pantai ditentukan dengan melihat jejak atau bekas airlaut di pantai saat pasang tertinggi.

2) Daerah pantai lumpur, garis pantai ditentukan dari pertemuan antara daratan (tanah keras) dengan daratan (lumpur) bekas pasang tertinggi.

3) Daerah pantai pepohonan, garis pantai diwakili oleh batas antara daratan tanah keras, sawah, bangunan, atau tambak terhadap tumbuhan yang berada pada perairan.

4) Daerah pantai buatan, garis pantai ditentukan berdasar garis batas terluar suatu bangunan permanen buatan manusia yang terletak di pinggir pantai.

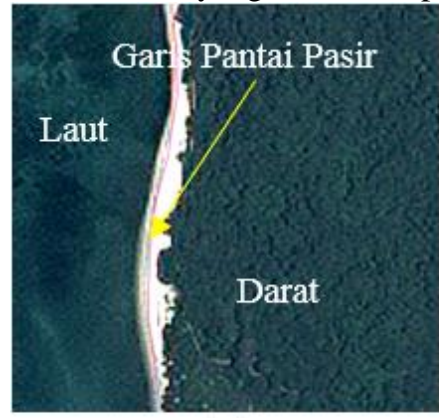

(a)

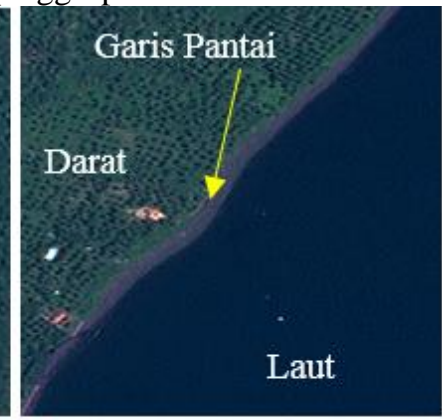

(b)
Gambar. 3. Hasil Digitasi Garis Pantai Pada Daerah Pantai Pasir (a) dan Pantai Lumpur (b)

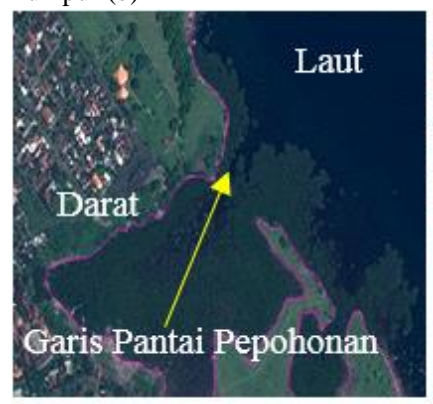

(a)

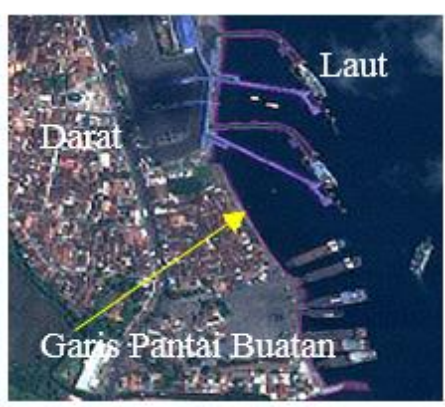

(b)
Gambar. 4. Hasil Digitasi Garis Pantai Pada Daerah Pantai Pepohonan (a) dan Pantai Buatan (b)

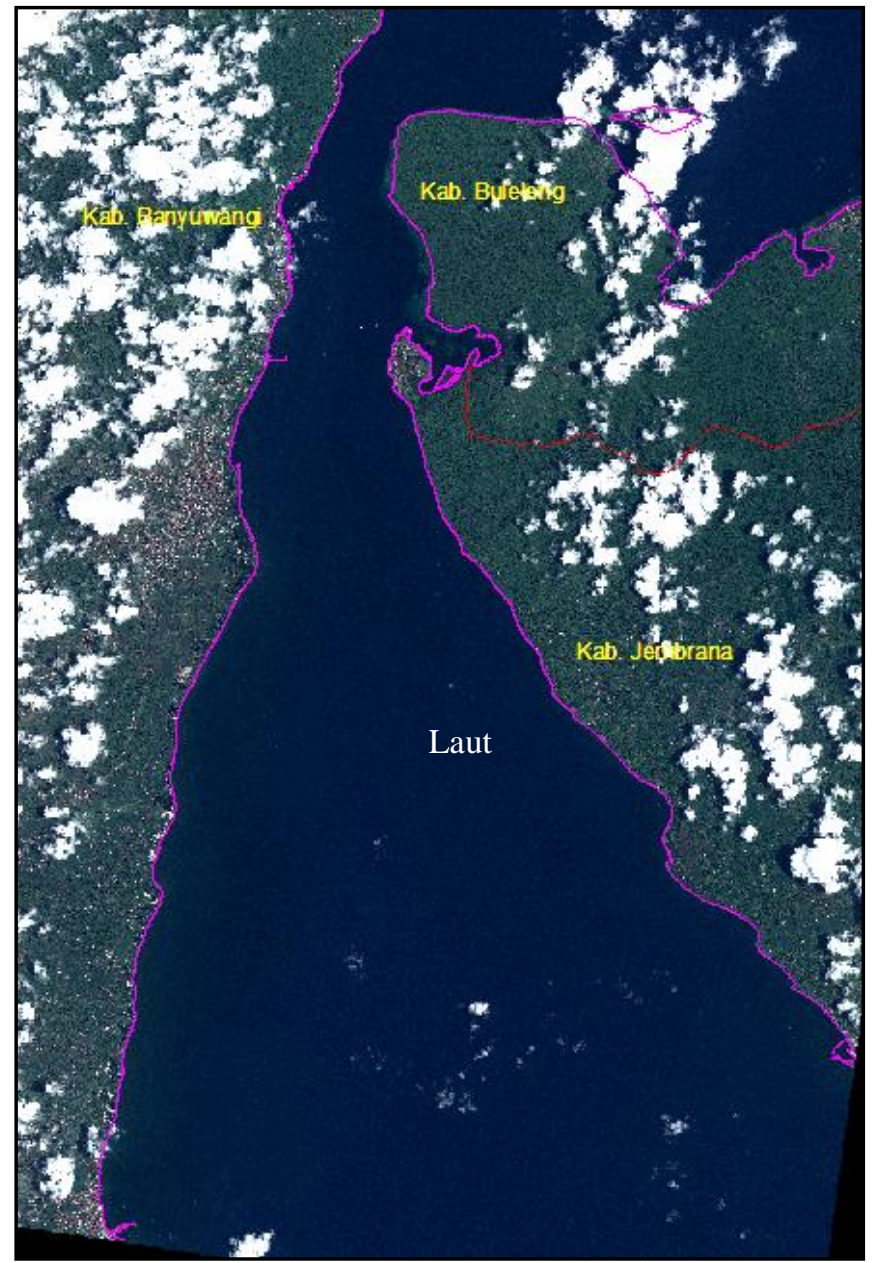

Gambar. 5. Hasil Digitasi Garis Pantai Keseluruhan pada Citra Satelit SPOT

\section{B. Hasil Penarikan Batas Pengelolaan Wilayah Laut Daerah Provinsi dengan Prinsip Median Line}

Penarikan batas pengelolaan wilayah laut daerah dengan prinsip median line dikarenakan jarak garis pantai antar kedua provinsi kurang dari 24 mil laut yaitu hanya sejauh 24.936,98 meter (13.5 mil laut). Sehingga apabila dilakukan buffering sejauh 12 mil laut dari masing-masing garis pantai, maka wilayah pengelolaan laut kedua provinsi akan saling tumpang tindih. Pada Undang-Undang Nomor 23 Tahun 2014 Pasal 27 ayat 3 ditetapkan bahwa batas pengelolaan wilayah laut antar daerah provinsi adalah paling jauh 12 mil laut yang diukur dari garis pantai ke arah laut lepas dari masing-masing provinsi. Selanjutnya pada ayat 4 dikatakan apabila wilayah laut antara dua daerah provinsi yang saling berbatasan kurang dari 24 mil laut maka pembagian kewenangan pengelolaan lautnya dibagi sama jarak atau diukur sesuai dengan prinsip garis tengah (median line).

Kondisi perbatasan antara Provinsi Jawa Timur dan Provinsi Bali yang berada pada Kabupaten Banyuwangi (Jawa Timur) dan Kabupaten Buleleng bagian barat sampai Kabupaten Jembrana (Bali) memiliki jarak yang kurang dari 24 mil laut. Oleh karena itu penarikan batas pengelolaan wilayah laut antar 
kedua provinsi ditentukan dengan prinsip garis tengah (median line).

Pada penelitian ini, penarikan batas pengelolaan wilayah laut dengan prinsip garis tengah dilakukan menggunakan perangkat lunak AutoCAD Map $3 D$ 2014. Penarikan garis batas pengelolaan wilayah laut dengan prinsip median line membutuhkan ketelitian dan kecermatan dalam menentukan titik-titik bantuan yang digunakan untuk membuat garis-garis konstruksi median line sehingga median line yang terbentuk tidak berat sebelah terhadap salah satu provinsi. Pada prinsip garis tengah (median line), setiap titik yang akan membentuk garis tengah merupakan perpotongan dari tiga garis-garis konstruksi yang memiliki panjang yang sama. Teknik yang digunakan dalam melakukan penarikan garis-garis konstruksi median line adalah dengan menggunakan garis bantu yang menghubungkan tiga buah titik kartometrik sehingga membentuk segitiga. Dari dua sisi segitiga yang melintasi batas antar kedua daerah, ditarik garis yang membagi dua sisi dan tegak lurus terhadap masing-masing sisi, sehingga titik perpotongan dari kedua garis tersebut akan menjadi titik yang membentuk garis tengah (median line) yang jaraknya sama dari ketiga titik kartometrik.

Menurut TALOS 1982 [4] pembentukan konstruksi equidistance lines dilakukan menggunakan metode Pure Graphical dan perhitungan titik balik yang butuh ketelitian dan keahlian serta cukup memakan waktu. Sehingga pada penelitian ini, pemilihan titik-titik dasar untuk pembentukan konstruksi equidistance line agar menghasilkan median line dilakukan secara subjektif pada data citra satelit Spot 7 menggunakan perangkat lunak AutoCAD Map 3D 2014.

Dari hasil penarikan garis tengah (median line) pada area batasan penelitian ini, dihasilkan median line sepanjang 40,3 $\mathrm{km}$ yang dibentuk oleh 41 titik kartometrik. Dan juga diperoleh luas wilayah pengelolaan wilayah laut masing-masing provinsi, yaitu:

Prov. Jawa Timur : 233.368.122,6988 $\mathrm{m}^{2}$ Prov. Bali $\quad: 233.769 .399,5349 \mathrm{~m}^{2}$.

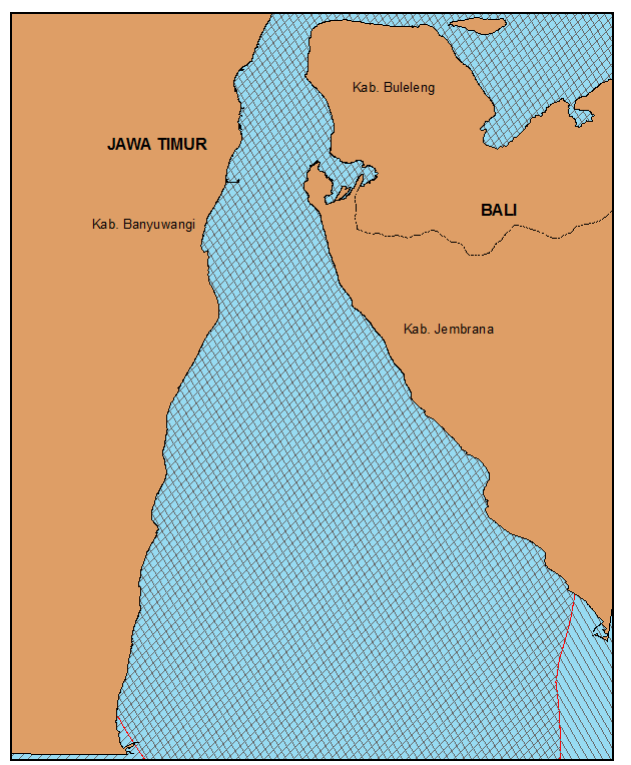

Gambar. 6. Hasil Buffering Sejauh 12 Mil Laut

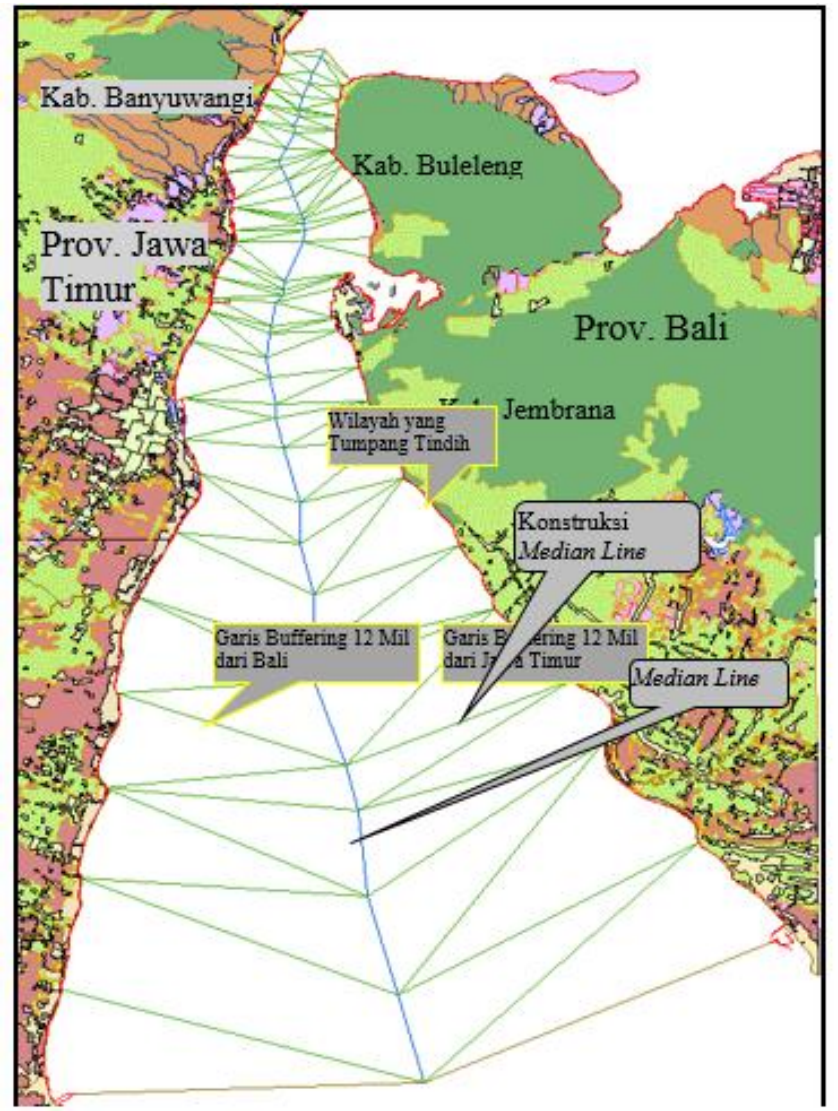

Gambar. 7. Hasil Penarikan Batas Pengelolaan Wilayah Laut Daerah Provinsi dengan Metode Prinsip Median Line

\section{Hasil Penarikan Batas Bagi Hasil Kelautan Kabupaten/Kota}

Pada pasal 14 ayat 6 Undang-Undang Nomor 23 Tahun 2014 dikatakan bahwa untuk daerah kabupaten/kota dapat memperoleh hasil kelautan yang berada pada batas wilayah 4 mil laut yang diukur dari garis pantai ke arah laut lepas atau ke arah perairan. Berbeda dengan Peraturan Menteri Dalam Negeri Nomor 76 Tahun 2012 [2] dimana pada Pasal 15 ayat 2b dikatakan bahwa batas antara dua daerah provinsi yang saling berhadapan dengan jarak kurang dari 24 mil laut diukur berdasarkan prinsip garis tengah dan kabupaten/kota yang saling berhadapan mendapat 1/3 bagian dari garis pantai ke arah garis tengah.

Sedangkan pada Undang-Undang Nomor 23 Tahun 2014 tidak dijelaskan mengenai batas wilayah bagi hasil kelautan apabila batas wilayah provinsi antar kabupaten/kota yang saling berbatasan kurang dari 24 mil laut. Oleh karena itu, untuk penarikan batas wilayah bagi hasil kelautan kabupaten/ kota yang batas wilayah laut provinsinya menggunakan prinsip median line karena tidak mencapai 12 mil laut adalah tetap sejauh 4 mil laut. 


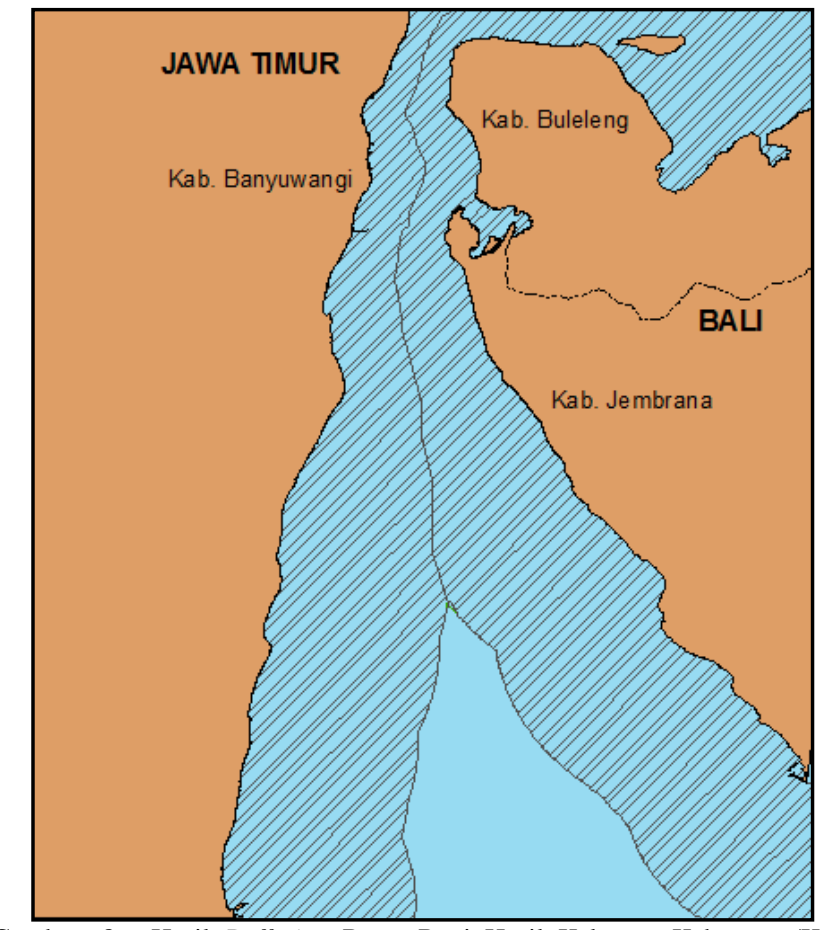

Gambar. 8. Hasil Buffering Batas Bagi Hasil Kelautan Kabupaten/Kota Sejauh 4 Mil

Kerterangan:

Iras : Batas bagi hasil sejauh 4 mil

\section{Hasil Penentuan Titik Kartometrik}

Pada penentuan batas pengelolaan wilayah laut, sebelum melakukan penarikan garis secara kartometrik terlebih dahulu dilakukan penentuan titik-titik kartometrik. Penentuan titik dasar pada citra satelit SPOT 7 diambil dari garis pantai dengan memilih titik dasar yang paling mencolok, mudah terlihat, dan tidak terlalu banyak memotong daratan [5]. Dalam menentukan titik-titik kartometrik, konfigurasi garis pantai sangat mempengaruhi jumlah dan jarak antar titik kertometrik.

Dapat dilihat pada Gambar 9, dimana konfigurasi garis pantai pada perbatasan antar Kabupaten Banyuwangi (Jawa Timur) dan Kabupaten Buleleng (Bali) lebih berliku dibandingkan pada perbatasan antara Kabupaten Banyuwangi dan Kabupaten Jembrana (Bali), sehingga jumlah titik kartometrik yang ada diantara Kabupaten Banyuwangi (Jawa Timur) dan Kabupaten Buleleng (Bali) lebih banyak dan juga jarak antar titik lebih rapat dibandingkan dengan yang berada pada perbatasan Kabupaten Banyuwangi (Jawa Timur) dan Kabupaten Jembrana (Bali). Selain pengaruh konfigurasi garis pantai, jarak antar garis pantai wilayah yang berbatasan juga sangat mempengaruhi jumlah dan jarak antar titik kertometrik. Seperti yang ditampilkan pada Gambar 8, dimana jarak garis pantai antara Kabupaten Banyuwangi terhadap Kabupaten Jembrana lebih besar dibandingkan jarak antara Kabupaten Banyuwangi dan Kabupaten Buleleng.

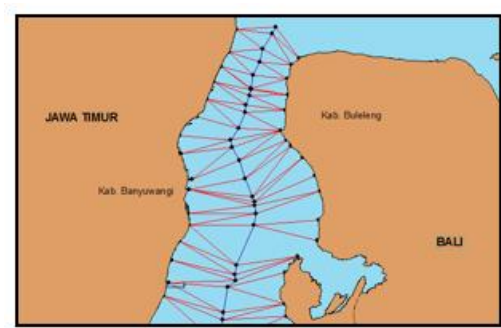

(a)

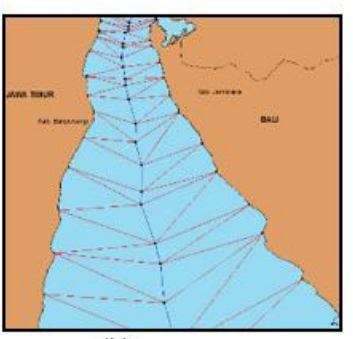

(b)
Gambar. 9. Titik Kartometrik Kab. Banyuwangi dan Kab. Buleleng (a), Kab. Banyuwangi dan Kab. Jembrana (b)

\section{E. Analisa Hasil Penarikan Batas Pengelolaan Wilayah Laut Daerah dengan Prinsip Median Line}

Metode median line pada dasarnya sama dengan metode equidistance line, karena garis tengah (median line) yang terbentuk merupakan kumpulan titik-titik potong dari garisgaris yang sama panjang (equidistance lines). Namun dalam penggunaannya, garis tengah (median line) biasanya digunakan untuk penentuan batas wilayah laut antar dua wilayah daratan yang saling berhadapan yang jaraknya tidak memenuhi batas maksimal masing-masing pihak sesuai ketetapan yang berlaku. Sedangkan equidistance lines biasanya digunakan untuk menentukan batas wilayah laut antar wilayah daratan yang saling berdampingan, dimana akan ditarik garis batas yang meneruskan batas daratan maupun batas laut yang merupakan median line, dengan menggunakan garis-garis yang sama jarak (equidistance lines) dari dua daratan yang berdampingan tersebut.

Berdasarkan A Manual on Technical Aspects of The United Nations Conventions on The Law of The Sea (TALOS 1982) [4], equidistance lines merupakan garis yang mewakili setiap titik yang berdekatan dan sama panjang yang berada pada dua wilayah yang berbatasan. Oleh karena itu, penentuan titik-titik dasar untuk equidistance lines dalam penarikan garis tengah sangat berpengaruh terhadap hasil akhir median line yang terbentuk. Pemilihan titik dasar juga dilakukan pada baseline (garis pantai) yang lebih menjorok ke arah laut. Semakin banyak pasangan titik dasar yang digunakan maka akan semakin baik pula konfigurasi penarikan garis batasnya. Dengan demikian jumlah titik dasar juga dipengaruhi oleh konfigurasi garis pantai masing-masih wilayah yang terkait dan jarak dari garis tengah ke titik dasar (basepoint) terdekat, sehingga semakin besar jarak antara garis pantai (baseline) terhadap garis tengah (median line) maka semakin sedikit pula pengaruh jumlah titik dasar (basepoints) yang ada di garis pantai serta semakin jauh jarak antar titik dasar pada garis pantai. Karena pengaruh konfigurasi garis pantai dari kedua wilayah yang berbatasan, median line yang dihasilkan belum tentu membagi dua wilayah laut sama besar. Oleh karena itu, akan terdapat selisih luas wilayah laut yang telah dibagi oleh median line.

Dalam penelitian ini, terdapat selisih luas wilayah pengelolaan laut antara Provinsi Jawa Timur dan Provinsi Bali sebesar $0,4 \mathrm{~km}^{2}$. Untuk lebih jelasnya dapat dilihat pada Tabel 1. 


\section{F. Analisa Selisih Luas Pengelolaan Wilayah Laut Daerah dengan Prinsip Median Line}

Berdasarkan hasil penarikan batas pengelolaan wilayah laut antara Provinsi Jawa Timur dan Provinsi Bali pada area batasan penelitian ini, setelah diperoleh luas masing-masing wilayah pengelolaan lautnya, terdapat selisih luas pengelolaan wilayah laut antar kedua provinsi sebesar 401.127,8361 $\mathrm{m}^{2}$.

Tabel 1.

Selisi Luas Wilayah Laut

\begin{tabular}{ccc}
\hline \hline Wilayah & Luas $\left(\mathrm{km}^{2}\right)$ & Pesentase \\
\hline Total Wilayah Penelitian & 467.14 & $100 \%$ \\
Wilayah Laut Jawa Timur & 233.37 & $49.95 \%$ Luas Total \\
Wilayah Laut Bali & 233.77 & $50.04 \%$ Luas Total \\
Selisih Luas & 0.40 & $0.08 \%$ Luas Total \\
\hline \hline
\end{tabular}

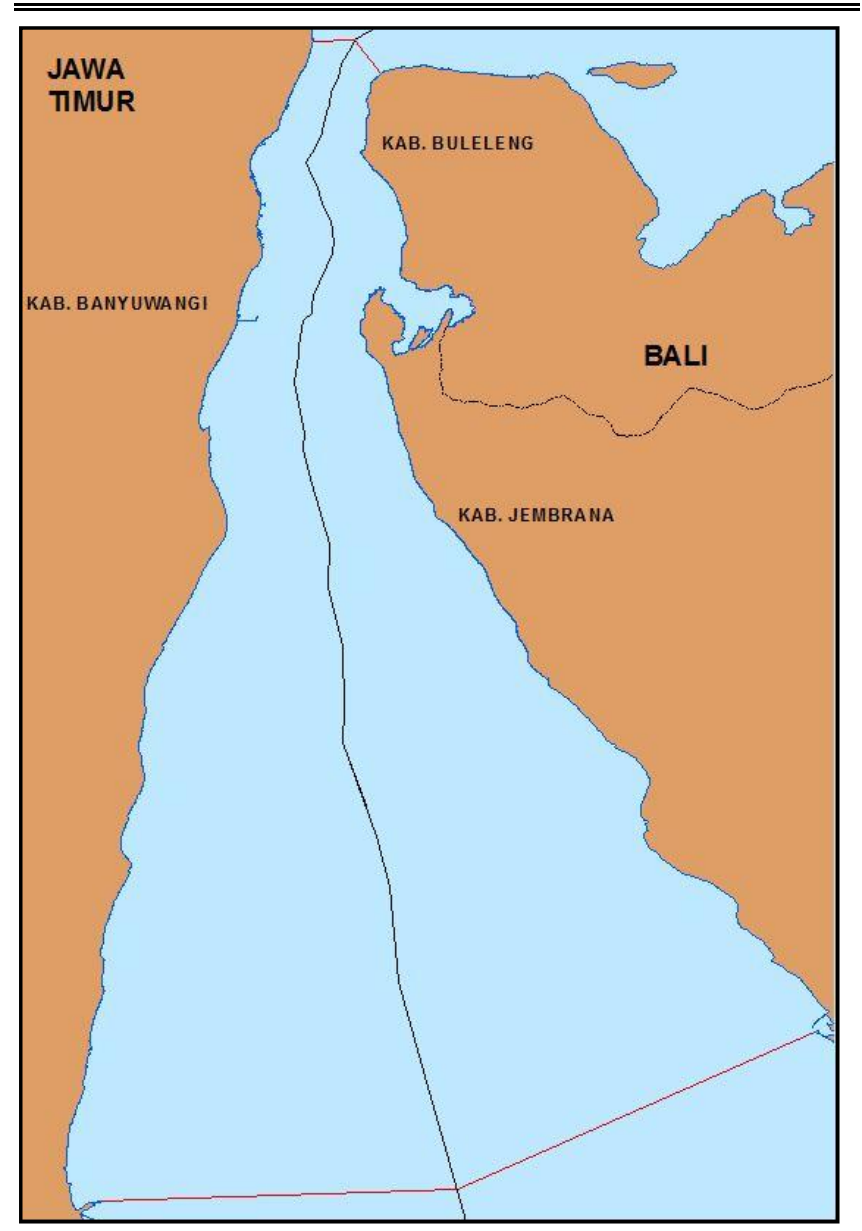

Gambar. 10. Luas Wilayah Pengelolaan Laut

Kerterangan:

: Garis Pantai

: Median Line

: Batasan Wilayah Total Penelitian

\section{KESIMPULAN}

Dari hasil penelitian ini maka dapat disimpulkan bahwa:

1) Dari hasil penarikan batas wilayah pengelolaan laut antara Provinsi Jawa Timur (Kab. Banyuwangi) dan Provinsi Bali (Kab. Buleleng - Kab. Jembrana) dengan prinsip median line berdasarkan Undang-Undang Nomor 23 Tahun 2014, dihasilkan median line sepanjang 40,3 $\mathrm{km}$ yang dibentuk oleh 41 titik kartometrik dengan konfigurasi yang lebih halus karena pengaruh perpaduan konfigurasi garis pantai dari kedua provinsi.

2) Jarak garis pantai terpanjang antara Provinsi Jawa Timur dan Provinsi Bali sesuai lokasi penelitian ini kurang dari 24 mil laut, yaitu hanya sejauh $25 \mathrm{~km}$ (13.5 mil laut) yang berada pada Kabupaten Banyuwangi (Jawa Timur) dan Kabupaten Jembrana (Bali), sehingga penentuan zona batas pengelolaan wilayah lautnya dilakukan dengan menggunakan prinsip sama jarak untuk menghasilkan garis tengah. Dari hasil penarikan garis tengah sesuai lokasi penelitian ini, diperoleh luas zona pengelolaan laut Provinsi Jawa Timur sebesar 233,37 km² dan Provinsi Bali sebesar $233.77 \mathrm{~km}^{2}$ dengan selisih sekitar $0,4 \mathrm{~km}^{2}$. Selisih luas diperoleh karena pengaru konfigurasi garis pantai kedua provinsi.

3) Dihasilkan Peta batas wilayah pengelolaan laut daerah Provinsi Jawa Timur (Kabupaten Banyuwangi) dan Provinsi Bali (Kabupaten Buleleng sampai Kabupaten Jembrana) dengan skala 1: 150.000 sebagai media yang menyajikan informasi-informasi terkait hasil penarikan batas wilayah pengelolaan laut daerah kedua provinsi serta batas wilayah bagi hasil kelautan kabupaten/kota yang sudah disesuaikan dengan Undang-Undang Nomor 23 Tahun 2014. Namun mengenai tutupan lahan masih menggunakan Peta LPI 2002.

\section{UCAPAN TERIMA KASIH}

Penulis, Rainhard S.S mengucapkan terima kasih kepada Dosen Pembimbing Jurusan Teknik Geomatika atas bimbingannya selama pelaksanaan penelitian, dan juga kepada Pusat Teknologi dan Data Penginderaan Jauh Lembaga Penerbangan dan Antariksa Nasional, Pusat Pemetaan Kelautan dan Lingkungan Pantai Badan Informasi Geospasial atas kesediaannya untuk memberikan dan mengizinkan penulis menggunakan data-data terkait dalam penelitian ini.

\section{DAFTAR PUSTAKA}

[1] R. Indonesia, "Undang-Undang No. 23 Tahun 2014 tentang Pemerintahan Daerah," Lembaran Negara RI Tahun 2014, No. 244. Sekretarian Negara. Jakarta., Indonesia, 2014.

[2] Y. Irwanto, 2013. [Online]. Available: http://www.bakosurtanal.go.id/berita-. [Accessed 20 Februari 2016].

[3] D. E. .. Poerbandono, Survei Hidrografi, Bandung, Indonesia: Refika Aditama., 2005..

[4] TALOS, "A Manual on Technical Aspect Of The United Nations Convention On The Law Of The Sea - 1982," Special Publication No. 51 4th - March 2006, International Hydrographic Bureau, Monaco, 2006.

[5] R. Widiastuty, "“Analisa Penetapan Batas Pengelolaan Laut Daerah Berdasarkan Peraturan Menteri Dalam Negeri Nomor 76 Tahun 2012 (Studi Kasus: Sengketa Pulau Galang Perbatasan Antara Kota Surabaya dan Kabupaten Geresik)"," Tugas Akhir Jurusan Teknik Geomatika FTSP ITS., Surabaya, 2014.

[6] . L. Hidayatno and H. Fahrul, "Penataan Btas Wilayah Administrasi Secara Bottom-Up.," Pusat Pemetaan Batas Wilayah Badan Informasi Geospasial. Jakarta.. 
[7] K. D. Negeri, "“'Peraturan Menteri Dalam Negeri Republik Indonesia No. 76 Tahun 2012 Tentang Pedoman Penegasan Batas Daerah".," Kementian Dalam Negeri, Jakarta, 2012.

[8] Anonim, "Map," National Geographic, 2012. 